\title{
saki
}

Studi Akuntansi \& Keuangan Indonesia

\section{Struktur Kepemilikan Institusional, Koneksi Politik dan Kebijakan Dividen Perusahaan di Bursa Efek Indonesia}

\author{
Novia Nursyahbandarmahdi, Siti Sarah, Luciana Haryono* \\ Sekolah Bisnis dan Ekonomi, Universitas Prasetiya Mulya \\ BSD City Kavling Edutown I. 1, Jl. BSD Raya Utama, BSD City, Tangerang 15339
}

\author{
Keywords : Institutional \\ Ownership, Political \\ Connections, Dividend \\ Policy
}

\section{Kata kunci: \\ Kepemilikan institusional, Koneksi Politik, Kebijakan Dividen \\ *Corresponding Author: luciana@pmbs.ac.id}

\begin{abstract}
:
The purpose of this study was to determine whether institutional ownership, political connections, and institutional ownership on politically connected companies affect the dividend policy of Indonesian companies listed on the Indonesian Stock Exchange from 2012 - 2017. The sample used in this study were 255 nonfinancial companies in Indonesia with total observations of 1554. The model used in this study was the Tobit regression model. The result shows that institutional ownership does not significantly influence dividend policy, whereas political connections on companies tend to support the payment of dividends to the shareholders. Furthermore, this study found that interaction between political connections and institutional ownership in the company does not significantly influence dividend policy.
\end{abstract}

\footnotetext{
Abstrak:

Tujuan dari penelitian ini adalah untuk mengetahui pengaruh kepemilikan institusional, koneksi politik pada perusahaan, dan kepemilikan institusional pada perusahaan dengan koneksi politik terhadap kebijakan dividen pada perusahaan yang terdaftar di Bursa Efek Indonesia pada tahun 2012-2017. Sampel yang digunakan pada penelitian ini berjumlah 255 perusahaan nonkeuangan di Indonesia dengan jumlah observasi sebanyak 1554. Metode penelitian yang digunakan pada penelitian ini adalah model regresi Tobit. Hasil penelitian menunjukkan bahwa kepemilikan institusional tidak berpengaruh signifikan terhadap kebijakan dividen, sedangkan koneksi politik pada perusahaan cenderung mendukung pembagian dividen kepada pemegang saham. Selain itu, penelitian ini menemukan bahwa interaksi antara koneksi politik dan kepemilikan institusional dalam perusahaan tidak mempengaruhi kebijakan dividen.
} 
Studi Akuntansi \& Keuangan Indonesia

\section{Pendahuluan}

Investasi merupakan faktor yang sangat krusial untuk berjalannya suatu perusahaan, sehingga sangat penting bagi perusahaan untuk dapat menarik para investor. Investor memutuskan untuk berinvestasi dalam suatu perusahaan guna mendapatkan keuntungan atau timbal balik investasi seperti dividen atau capital gain (Nugraheni dan Mertha, 2019). Dividen merupakan salah satu elemen pendistribusian laba yang memiliki keterkaitan erat dengan implementasi dari objektif strategis dari sebuah perusahaan (Zygula, 2017) dan sebagai alat yang digunakan untuk mengurangi agency cost dalam perusahaan dengan cara mengharuskan pemegang saham pengendali untuk membagikan kekayaannya kepada pemegang saham lain (Faccio, Lang \& Young, 2001).

Indonesia merupakan negara yang masih berkembang dengan populasi negara yang besar. Perdagangan saham di Indonesia telah menarik perhatian macam-macam investor, termasuk investor institusional baik dari dalam negeri maupun luar negeri. Pemegang saham institusional dalam perusahaan memiliki sejumlah peran penting, salah satunya merupakan fungsi pengawasan yang ditemukan dapat mengurangi konflik agensi dalam perusahaan dikarenakan kepemilikannya yang berjumlah besar (Benjamin, Wahab, \& Zain 2016). Kapasitas pengawasan dari investor institusional diteliti dapat memengaruhi kualitas manajemen yang lebih baik terutama dalam menjalankan perusahaannya (Larkin, Leary, dan Michaely, 2016). Selain itu, pemegang saham institusional juga cenderung lebih fokus kepada profitabilitas perusahaan yang tinggi untuk mendapatkan jumlah dividen yang lebih besar (Ayers, Ramalingegowda \& Yeung, 2011). Maka dari itu kepemilikan institusional dapat menjadi salah satu faktor yang memengaruhi jumlah dividen yang dibagikan oleh perusahaan. Dividen dapat menjadi alat dalam memberikan sinyal bagi para pemegang saham untuk menanamkan modalnya dalam sebuah perusahaan (Gitman, Smart \& Megginson, 2007). 


\section{saki}

Studi Akuntansi \& Keuangan Indonesia

Thanatawee (2013) menemukan bahwa perusahaan di Thailand dengan persentase kepemilikan institusional yang lebih tinggi cenderung membayar dividen lebih banyak kepada para pemegang sahamnya. Berbeda dengan Thailand, Indonesia yang diklasifikasikan sebagai salah satu emerging market (Nys, Tarazi, dan Trinugroho, 2015), dikatakan memiliki kecenderungan membagikan jumlah dividen yang lebih kecil kepada pemegang saham minoritasnya dikarenakan adanya pengambilalihan oleh pemegang saham pengendali (Bandi et al., 2015). Selain Indonesia, Balagobei dan Thiruchchenthurnathan (2016) menemukan bahwa struktur kepemilikan individual dan institusional tidak memiliki korelasi yang signifikan dengan kebijakan pembayaran dividen di Sri Lanka. Banyak dari investor negara industri menahan saham mereka dalam pasar yang sedang berkembang sebagai tujuan jangka panjang dan bukan hanya semata-mata hanya untuk mendapatkan kas dividen yang bersifat jangka pendek (Glen, Karmokolias, Miller \& Shah, 1995) yang menjadikan hubungan antara keduanya menjadi negatif.

Selain kepemilikan institusional, variabel politik juga menjadi salah satu faktor yang dapat memengaruhi keputusan kebijakan pembagian dividen sebuah perusahaan. Peran penting perusahaan dengan koneksi politik pada perekonomian negara non-barat telah meningkat pada dekade terakhir (Bliss dan Gul, 2012). Indonesia merupakan negara yang ideal untuk meneliti isu ini dikarenakan Indonesia merupakan salah satu negara dengan lebih dari sepuluh persen perusahaan terdaftarnya merupakan perusahaan dengan koneksi politik (Faccio, 2006). Perusahaan dengan hubungan politik atau disebut Politically Connected Companies (PCC) cenderung memiliki akses dan keuntungan yang lebih besar dalam pasar dibandingkan perusahaan yang tidak memilikinya (Grinblatt dan Keloharju, 2000; Purbasari, 2006). Adanya hubungan politik juga dapat memengaruhi kebijakan yang berlaku bagi perusahaan terutama ketika terdapat perubahan kebijakan ataupun peraturan yang dibuat oleh pemerintah sehingga salah satu pihak yang paling dahulu dan mudah dipengaruhi oleh perubahan tersebut adalah PCC. 


\section{saki}

Studi Akuntansi \& Keuangan Indonesia

Dilihat dari adanya hubungan saling memengaruhi variabel-variabel tersebut, maka penelitian ini dibuat dengan motivasi untuk mengidentifikasi dan memaparkan hubungan-hubungan antara kepemilikan institusional, hubungan politik, dan kebijakan pembagian dividen di Indonesia. Apabila ditelusuri dari sejumlah penelitian terdahulu yang telah membahas isu mengenai tiga variabel ini, menunjukkan hasil yang inkonsisten. Penelitian yang mengangkat kepemilikan institusional dihubungkan dengan koneksi politik dan dividen belum banyak di Indonesia. Maka dari itu, Indonesia merupakan negara yang ideal untuk digunakan untuk meneliti topik ini. Penelitian menggunakan sampel sebanyak 1554 observasi dengan menggunakan 255 perusahaan non-keuangan yang terdaftar di Bursa Efek Indonesia (BEI) dari tahun 2012 hingga 2017.

\section{Telaah Literatur dan Pengembangan Hipotesis}

\section{Agency Theory}

Hubungan keagenan merupakan sebuah kontrak antara satu orang atau lebih (principal) yang mempekerjakan orang lain (agen) untuk melaksanakan sebuah jasa atas nama principal yang melibatkan pengambilan keputusan oleh agen (Jensen dan Meckling, 1976). Dalam literaturnya juga diilustrasikan bahwa adanya kepemilikan pemegang saham manajerial yang besar dapat mengurangi biaya keagenan apabila perusahaan dikelola 100\% oleh pemiliknya sendiri. Dalam buku Agency Cost Model oleh Megginson dan Smart (2008), diasumsikan bahwa pembagian dividen timbul untuk mengatasi masalah keagenan yang dapat terjadi saat pemisahan kepemilikan dan penguasaan perusahaan. Kepemilikan yang pada awalnya masih terkonsentrasi, ke depannya akan tersebar seiring dikeluarkannya modal ekuitas dan para pemegang saham mulai mendiversifikasi kepemilikannya.

\section{Struktur Kepemilikan Institusional}

Kepemilikan institusional adalah kepemilikan saham oleh pihak-pihak yang berbentuk institusi seperti yayasan, bank, perusahaan asuransi, perusahaan investasi, dana pensiun, perusahaan berbentuk perseroan (PT), dan institusi lainnya (Edison, 2017). 
Studi Akuntansi \& Keuangan Indonesia

Kepemilikan saham ini akan mewakili suatu sumber kekuasaan yang dapat digunakan untuk mendukung atau sebaliknya terhadap kinerja manajemen. (Kurniawati, Manalu, \& Octavianus, 2015; Rais \& Santoso, 2017).

Dalam penelitian ini, kriteria kepemilikan institusional merupakan perusahaan yang terdaftar di BEI sejak tahun 2012 hingga 2017 dengan persentase investasi oleh pemegang institusional dari total keseluruhan kepemilikan dalam perusahaan. Nugraheni dan Mertha (2019) menyebutkan apabila dibandingkan dengan seluruh persentase kepemilikan dalam suatu perusahaan, kepemilikan institusional menjadi pemegang saham terbesar dalam perusahaan sehingga para investor institusional memiliki wewenang yang lebih besar dalam mengontrol dan mengawasi kinerja manajemen sehingga mengurangi masalah keagenan yang dapat terjadi dan meningkatkan laba perusahaan.

\section{Koneksi Politik}

Faccio (2006) menyatakan bahwa perusahaan dengan hubungan politik cenderung memiliki kekuatan pasar yang lebih tinggi dibandingkan perusahaan yang tidak memiliki hubungan politik. Fung et al. (2014) membahas mengenai kebijakan dividen di China yang dipengaruhi oleh masalah keagenan dan koneksi politik. Mereka menemukan perusahaan yang memiliki koneksi politik dalam perusahaannya akan membayar dividen lebih banyak dibandingkan dengan perusahaan yang tidak memiliki koneksi politik. Habib dan Muhammadi (2018) memodifikasi kriteria yang diadopsi oleh Faccio (2006) dengan penyesuaian yang mengklasifikasikan observasinya sebagai perusahaan dengan koneksi politik bila setidaknya satu pemegang saham pengendali (mengendalikan setidaknya sepuluh persen dari suara langsung atau tidak langsung) atau Dewan Direksi atau Komisaris merupakan anggota atau mantan anggota dari parlemen, menteri atau kepala dari pemerintahan lokal atau memiliki hubungan dekat dengan seorang politisi atau sebuah partai. Koneksi politik yang dimaksud berupa kerabat dekat (pasangan, anak laki-laki atau perempuan, dan hubungan keluarga dekat lainnya). 
Studi Akuntansi \& Keuangan Indonesia

\section{Kebijakan Dividen}

Gitman et al. (2007) menyatakan bahwa kebijakan dividen merupakan pilihan yang dibuat perusahaan untuk menentukan apakah akan membayar dividen ke pemegang saham, seberapa besar cash dividend yang akan dibagikan, dan seberapa seringkah dividen dibagikan. Menurut Shim et al. (2007), kebijakan dividen dalam perusahaan memiliki sejumlah kepentingan yaitu pengaruhnya terhadap sikap investor, program keuangan dan anggaran modal perusahaan, posisi arus kas perusahaan, serta dapat memperkecil ekuitas yang dimiliki pemegang saham. Easterbrook (1984) dan Jensen (1986) menunjukkan bahwa peningkatan pembagian dividen dapat meringankan konflik keagenan dikarenakan manajer cenderung lebih memilih untuk menyimpan laba ditahan untuk meningkatkan konsumsi perusahaan atau mengurangi risiko pada sumber daya manusia yang dimiliki.

\section{The Tax-Effect Hypothesis}

Miller dan Modigliani (1961) menjelaskan pada penelitiannya mengenai kebijakan dividen bahwa asumsinya mengenai pasar modal yang sempurna mengecualikan seluruh kemungkinan adanya dampak pajak dalam pasar modal. Pada penelitian tersebut diasumsikan tidak ada perbedaan perlakuan pajak antara pembagian dividen dan capital gain. Al-Malkawi, Pillai dan Rafferty (2010) berargumen bahwa dalam dunia nyata pajak memiliki dampak dan memiliki pengaruh yang signifikan terhadap kebijakan dividen dan nilai dari perusahaan. Penelitian mereka menjelaskan bahwa umumnya terdapat perbedaan perlakukan pajak untuk pembagian dividen dan capital gain, dan sebagian besar pemegang saham lebih tertarik pada pengembalian setelah pajak sehingga pajak dapat mempengaruhi permintaan pemegang saham atas pembagian dividen. The tax-effect hypothesis menjelaskan bahwa rasio pembagian dividen yang kecil akan memperkecil cost of capital dan meningkatkan harga saham perusahaan.

\section{Signaling Effect}


Studi Akuntansi \& Keuangan Indonesia

Gitman et al. (2007) menjelaskan bahwa signaling model of dividend mengasumsikan bahwa manajer menggunakan dividen untuk menyampaikan informasi positif terhadap pemegang saham yang kekurangan informasi. Seorang investor atau sebuah perusahaan memiliki preferensinya sendiri terhadap kebijakan dividen perusahaannya. Grinstein dan Michaely (2005) dalam Cao et al. (2017) menunjukkan bahwa investor institusional lebih memilih dividen untuk laba ditahan dikarenakan perusahaan yang membagikan dividen dengan stabil dianggap sebagai investasi yang bijaksana.

\section{Pengembangan Hipotesis}

\section{Kepemilikan Institusional dan Pembagian Dividen}

Teori keagenan membahas konflik antara pemegang saham dengan sebuah pihak dalam perusahaan yang dapat berupa manajer, sesama pemegang saham dalam perusahaan dan kreditor. Masalah yang timbul umumnya berupa manajemen yang berfungsi merepresentasikan pemegang saham untuk memberikan penghasilan kepada mereka, sementara manajer lebih memilih untuk menyimpan penghasilan perusahaan untuk diinvestasikan kembali ke dalam perusahaan daripada membagikannya kepada pemegang saham perusahaan. Manajer cenderung menggunakan kekuasaannya di perusahaan untuk melakukan investasi yang dianggap dapat memberikan mereka keuntungan tanpa mempertimbangkan penghasilan atau kerugian yang akan didapatkan oleh pemegang saham perusahaan (Jensen dan Meckling, 1976).

Pembagian dividen jika dibagikan secara rata ditemukan dapat mengurangi biaya keagenan dikarenakan dapat mengurangi free cash flow dalam perusahaan. (Easterbrook, 1984; Jensen, 1986). Jensen (1986) menjelaskan kegunaan pembagian dividen dalam perusahaan dapat mendorong manajer untuk mengembalikan dividen kepada pemegang saham daripada melakukan investasi berlebih dan menyia-nyiakan sumber daya perusahaan. Hipotesis keagenan mendukung bahwa pembagian dividen yang besar dapat 
Studi Akuntansi \& Keuangan Indonesia

memperingan fungsi pengawasan pemegang saham maka akan berdampak pada berkurangnya kemungkinan adanya investasi yang berlebihan.

La Porta et al., (2000) menemukan bahwa perusahaan di dalam negara yang memiliki proteksi atas pemegang saham minoritas yang baik cenderung membagikan dividen yang lebih banyak kepada pemegang sahamnya dibandingkan perusahaan yang berada pada negara yang kurang memiliki proteksi atas pemegang saham minoritasnya. Penemuan tersebut mendukung penemuan mereka bahwa negara yang menganut civil law cenderung lebih sedikit membagikan dividen daripada negara yang menganut common law. Indonesia merupakan salah satu negara yang menganut sistem civil law. Dalam literatur oleh Faccio et al. (2001), ditemukan bahwa Indonesia merupakan salah satu negara dimana pasar modal belum bisa menjaga expropriation harta dalam perusahaan. Tentunya Indonesia masih dalam kelompok negara dengan pasar modal yang masih berkembang.

Thanatawee (2013) telah menguji peran kepemilikan institusional di Thailand sebagai salah satu negara yang juga masih berkembang dan menganut sistem civil law di Asia Tenggara. Dalam penelitiannya, ditemukan bahwa perusahaan dengan investor institusional sebagai pemegang saham mayoritas cenderung membagikan dividen dan memiliki hubungan positif terhadap pembagian dividen. Selain itu, perusahaan cenderung akan membayar dividen dan membagikan dividen semakin besar jika memiliki kepemilikan institusional yang semakin besar. Hal ini didukung dengan adanya fungsi pengawasan yang dilakukan oleh pemegang saham institusional dan keefektifan dalam memengaruhi manajer dalam membagikan dividen yang lebih banyak (Jensen, 1986).

H1. Kepemilikan institusional yang tinggi berpengaruh positif terhadap pembagian dividen di Perusahaan yang terdaftar di BEI.

\section{Political Connection dan Pembagian Dividen}

Faccio et al. (2001) menunjukkan bahwa masalah keagenan yang sangat terlihat dalam negara yang berada pada Asia Timur adalah masalah pengambilalihan harta dari 


\section{Studi Akuntansi \& Keuangan Indonesia}

pemegang saham luar. Pembagian dividen dapat menjadi solusi atas jumlah dari ketersediaan free cash flow yang dapat digunakan oleh manajemen (Jensen, 1986). Selain itu, jumlah dari dividen yang dibagikan oleh perusahaan, dapat memberikan indikasi terjadinya pengambilalihan oleh insider (Faccio et al. 2001).

Indonesia, dan negara berkembang lainnya seperti Malaysia dan Thailand, merupakan salah satu contoh dari pasar modal berkembang yang didominasi oleh perusahaan dengan koneksi politik (Faccio, 2006). Dalam berkompetisi atas pemindahan harta dari politisi, perusahaan dengan koneksi politik dapat menawarkan dukungan dengan bentuk uang atau donasi kepada politisi atau sebuah partai politik, sebagai gantinya mendapatkan dukungan dari pemerintah pertimbangan prioritas untuk proyek-proyek, atau harapan bahwa mereka akan dibantu oleh pemerintah ketika mengalami kesulitan keuangan (Faccio 2006). Selain untuk dibagikan sebagai dividen, kas dalam perusahaan dapat dipergunakan atau dialihkan oleh insider yang berkuasa (Easterbrook, 1984; Jensen, 1986) untuk kepentingan pribadi atau diinvestasikan ke dalam proyek yang tidak menguntungkan yang dapat memberikan manfaat untuk mereka sendiri (Benjamin et al., 2016). Berdasarkan argumen tersebut, penulis membangun hipotesis berikut.

H2: Perusahaan dengan koneksi politik yang kuat berpengaruh negatif terhadap kebijakan pembagian dividen.

Politically Connected Firms yang memiliki kepemilikan institusional dan Kebijakan Dividen

Sejumlah penelitian terdahulu telah membahas manfaat yang didapatkan perusahaan yang memiliki koneksi politik, seperti memiliki pengaruh kepemerintahan dalam mendapatkan kontrak dengan institusi negara (Goldman, Rocholl \& So, 2009), membayar pajak lebih rendah, menghemat biaya operasional (Faccio, 2006). Leuz dan OberholzerGee (2006) menjelaskan dalam penelitiannya bahwa perusahaan dengan koneksi politik 


\section{saki}

Studi Akuntansi \& Keuangan Indonesia

yang kuat dapat menarik lebih banyak peluang bisnis, perusahaan dengan koneksi yang kuat dan tumbuh cepat dapat menarik investor-investor besar.

Pengaruh kepemilikan institusional mayoritas dalam perusahaan telah diteliti dapat mengurangi tingkat masalah keagenan dalam perusahaan menggunakan peran pengawasan pemegang saham (Shleifer dan Vishny, 1986). Menurut Shin dan Seo (2011), kepemilikan institusional yang substansial mendorong mereka untuk meningkatkan tingkat pengawasan dalam perusahaan dikarenakan adanya keahlian dan koneksi yang kuat. Selain itu, adanya theory of voice atau hak suara dalam perusahaan, sehingga adanya kemungkinan investor institusional dapat memengaruhi tata kelola perusahaan secara keseluruhan. Seperti dalam penelitian Chung dan Zhang (2011) yang menemukan bahwa pengawasan yang dilakukan investor institusional yang aktif memiliki hubungan dengan pengangkatan Direksi yang kompeten dan independen pada manajemen dan komite audit.

Melanjutkan hubungan antara perusahaan dengan hubungan politik terhadap kepemilikan institusional, penelitian ini juga ingin melihat dan mengidentifikasi hubungan lebih jauh antara PCC yang memiliki kepemilikan institusional yang tinggi terhadap kebijakan dividen perusahaan. Pengawasan oleh investor institusional juga merupakan pengawas yang kuat dalam politically connected firms (PCC) dan di dalam penelitian Haron, James, Wahab dan Zain (2009) pada perusahaan di Malaysia, kepemilikan institusional pada PCC dapat mengurangi kebiasaan pengambilalihan dalam PCC. Investor institusional dapat mengawasi aktivitas atau kebiasaan dari pengambilalihan yang terjadi di PCC dan menggunakan kepentingannya di dalam perusahaan untuk mendorong PCC untuk membagikan kas perusahaan dalam bentuk dividen, yang kemungkinan akan digunakan untuk tujuan yang tidak dalam satu visi dengan pemegang saham lainnya (Shleifer dan Vishny, 1997). Maka dari itu penulis membangun hipotesis berikut:

H3: Politically Connected Firms yang memiliki kepemilikan institusional yang tinggi berpengaruh positif terhadap kebijakan dividen. 
Studi Akuntansi \& Keuangan Indonesia

\section{Kerangka Penelitian}

Berdasarkan literatur review dan pengembangan hipotesis di atas, dapat disusun kerangka penelitian sebagai berikut:

Variabel Independen

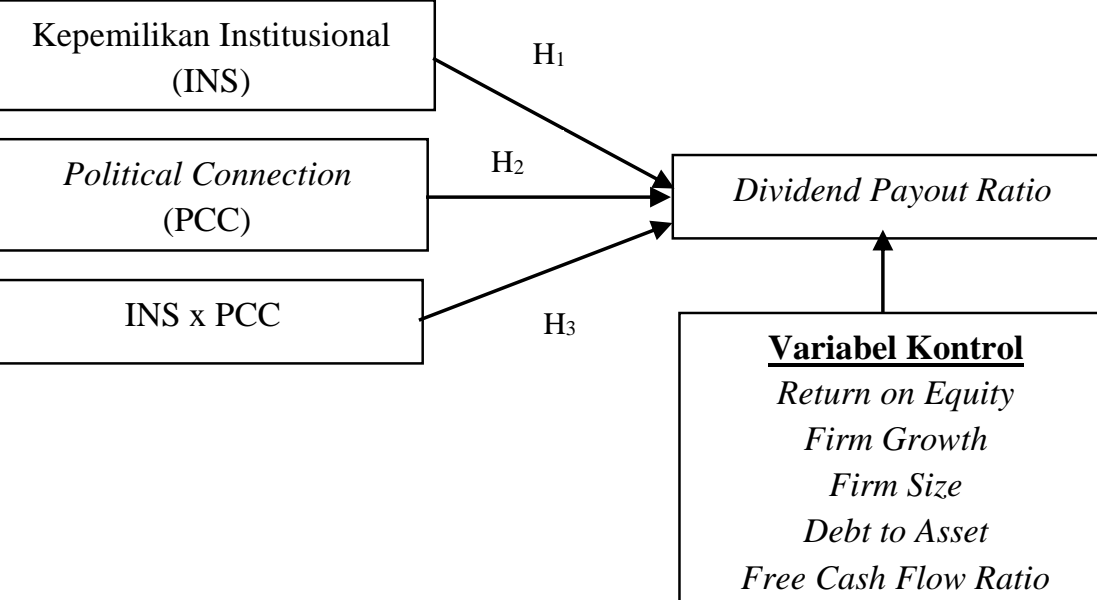

\section{Gambar 1. Kerangka Penelitian}

\section{Metode Penelitian}

\section{Pemilihan dan pengumpulan data}

Penelitian ini menggunakan data sekunder yang diperoleh dari laporan tahunan perusahaan yang tersedia dalam Bursa Efek Indonesia dan website resmi perusahaan, serta Capital IQ selama tahun 2012 hingga tahun 2017.

\section{Populasi dan Sampel}

Populasi data yang digunakan dalam penelitian ini bersumber dari terminal data Capital IQ dan Laporan Tahunan perusahaan-perusahaan non-finansial yang terdaftar di Bursa Efek Indonesia (BEI) dari tahun 2012 hingga tahun 2017. Sampel diambil menggunakan teknik purposive sampling, sedangkan data dipilih secara sengaja berdasarkan kriteria yang telah ditentukan pada penelitian ini. Daftar perolehan sampel penelitian tertera pada tabel berikut: 
Tabel 1 Kriteria Sampel Penelitian

\begin{tabular}{|l|r|}
\hline \multicolumn{1}{|c|}{ Kriteria } & \multicolumn{1}{|c|}{$\begin{array}{c}\text { Jumlah } \\
\text { Perusahaan }\end{array}$} \\
\hline Jumlah perusahaan non-keuangan yang terdaftar di Bursa Efek Indonesia & 510 \\
\hline $\begin{array}{l}\text { Jumlah perusahaan non-keuangan yang terdaftar di BEI yang melakukan } \\
\text { Initial Public Offering (IPO) setelah tahun 2012 }\end{array}$ & 115 \\
\hline $\begin{array}{l}\text { Jumlah perusahaan non-keuangan yang terdaftar di BEI yang melakukan IPO } \\
\text { pada atau sebelum tahun 2012, namun tidak memiliki data keuangan yang } \\
\text { lengkap }\end{array}$ & \\
\hline Data outliers & (4) \\
\hline Perusahaan yang memenuhi kriteria sampel penelitian & 255 \\
\hline
\end{tabular}

(Sumber: Olah Data, 2019)

\section{Pengukuran dan Operasionalisasi Variabel Penelitian}

Penelitian memiliki dua variabel independen yaitu Kepemilikan Institusional dan Koneksi Politik dalam perusahaan (Benjamin et al., 2016). Selain itu, variabel dependen yang digunakan adalah Dividend Payout Ratio untuk menghitung kebijakan dividen perusahaan (La Porta et al., 2000). Penelitian ini juga menggunakan lima jenis variabel kontrol yakni firm size, firm growth, return on equity, debt-to-asset ratio, dan free cash flow ratio. Berikut ini adalah penjelasan mengenai definisi operasional variabel penelitian.

Tabel 2 Operasionalisasi Variabel Penelitian

\begin{tabular}{|l|l|l|l|}
\hline No & \multicolumn{1}{|c|}{ Variabel } & \multicolumn{1}{c|}{ Proksi } & \multicolumn{1}{c|}{ Rumus } \\
\hline \multicolumn{3}{|c|}{ Variabel Dependen } \\
\hline 1. & $\begin{array}{l}\text { Dividend Payout Ratio } \\
\text { (DPR) }\end{array}$ & $\begin{array}{l}\text { Total dividen dibagi dengan total } \\
\text { laba bersih }\end{array}$ & $\frac{\text { Dividend per Share }}{\text { Earning per Share }}$ \\
\hline
\end{tabular}

\begin{tabular}{|l|l|l|l|}
\hline \multicolumn{2}{|c|}{ Variabel Independen } \\
\hline 2. & $\begin{array}{l}\text { Struktur } \\
\text { Kepemilikan } \\
\text { Institusional (INS) }\end{array}$ & $\begin{array}{l}\text { Persentase jumlah } \\
\text { kepemilikan saham } \\
\text { oleh investor } \\
\text { institusional dari } \\
\text { seluruh saham }\end{array}$ & $\frac{\text { Jumlah saham oleh investor institusional }}{\text { Total saham dalam perusahaan }} \times 100$ \\
\hline
\end{tabular}


Studi Akuntansi \& Keuangan Indonesia

\begin{tabular}{|c|c|c|c|}
\hline & & $\begin{array}{l}\text { beredar dalam } \\
\text { perusahaan }\end{array}$ & \\
\hline 3. & $\begin{array}{l}\text { Politically } \\
\text { Connected } \\
\text { Companies (PCC) }\end{array}$ & $\begin{array}{l}\text { Adanya pemegang } \\
\text { saham pengendali } \\
\text { dan/atau anggota } \\
\text { Dewan Direksi } \\
\text { memiliki koneksi } \\
\text { politik }\end{array}$ & $\begin{array}{l}\text { Menggunakan variabel dummy dimana } \\
\text { perusahaan dengan koneksi politik dinilai } 1 \text { dan } \\
\text { perusahaan yang tidak memiliki koneksi politik } \\
\text { akan bernilai } 0 \\
\text { Contoh : bila suatu perusahaan memenuhi salah } \\
\text { satu kriteria koneksi politik menurut Habib dan } \\
\text { Muhammadi (2018) misal terkait dengan partai } \\
\text { politik atau kerabat politisi tertentu maka diberi } \\
\text { nilai } 1 \text {, sedang bila tidak maka diberi nilai } 0 \text {. }\end{array}$ \\
\hline
\end{tabular}




\begin{tabular}{|l|l|l|l|}
\hline \multicolumn{3}{|c|}{ Variabel Kontrol } \\
\hline 4. & Firm size (SIZE) & Logaritma dari total asset & \multicolumn{1}{c|}{ Log(Total Assets) } \\
\hline 5. & $\begin{array}{l}\text { Firm Growth } \\
\text { (GROWTH) }\end{array}$ & $\begin{array}{l}\text { Persentase pertumbuhan } \\
\text { penjualan perusahaan selama 1 } \\
\text { tahun }\end{array}$ & $\frac{\text { Penjualan } t-\text { penjualan }(t-1)}{\text { penjualan }(t-1)}$ \\
\hline 6. & $\begin{array}{l}\text { Return on Equity } \\
\text { (ROE) }\end{array}$ & $\begin{array}{l}\text { Pengembalian laba dari ekuitas } \\
\text { perusahaan }\end{array}$ & $\frac{\text { Taba bersih }}{\text { Total equitas }}$ \\
\hline 7. & $\begin{array}{l}\text { Debt-to-Asset } \\
\text { Ratio (DEBT) }\end{array}$ & $\begin{array}{l}\text { Pembiayaan aset perusahaan } \\
\text { yang berasal dari debt }\end{array}$ & $\frac{\text { Total Debt }}{\text { Total assets }}$ \\
\hline 8. & $\begin{array}{l}\text { Free Cash Flow } \\
\text { Ratio (FCF) }\end{array}$ & $\begin{array}{l}\text { Kas yang ada dalam aktivitas } \\
\text { operasi }\end{array}$ & $\frac{\text { Kas dari aktivitas operasi }}{\text { Penjualan }}$ \\
\hline
\end{tabular}

(Sumber: Olah Data, 2019)

\section{Model Penelitian}

Masing-masing hipotesis dalam penelitian ini diuji menggunakan tiga model penelitian yang berbeda. Berikut merupakan model penelitian yang digunakan untuk menguji masing-masing hipotesis.

Model pengujian untuk H1 (Institutional - Dividend)

$$
\begin{aligned}
D P R_{i t}=\alpha_{0}+ & \alpha_{1} I N S_{i t}+\alpha_{2} R O E_{i t}+\alpha_{3} S I Z E_{i t}+\alpha_{4} G R O W T H_{i t}+\alpha_{6} D E B T_{i t} \\
& +\alpha_{7} F C F_{i t}+\varepsilon
\end{aligned}
$$

Model pengujian untuk H2 (PCC - Dividend)

$$
\begin{aligned}
D P R_{i t}=\alpha_{0}+ & \alpha_{1} P C C_{i t}+\alpha_{2} R O E_{i t}+\alpha_{3} S I Z E_{i t}+\alpha_{4} G R O W T H_{i t}+\alpha_{6} D E B T_{i t} \\
& +\alpha_{7} F C F_{i t}+\varepsilon
\end{aligned}
$$

$\underline{\text { Model pengujian untuk H3 (Moderasi) }}$

$$
\begin{gathered}
D P R_{i t}=\alpha_{0}+\alpha_{1} I N S_{i t}+\alpha_{2} P C C_{i t}+\alpha_{3} I N S * P C C_{i t}+\alpha_{4} R O E_{i t}+\alpha_{5} S I Z E_{i t} \\
+\alpha_{6} G R O W T H_{i t}+\alpha_{7} D E B T_{i t}+\alpha_{8} F C F_{i t}+\varepsilon
\end{gathered}
$$


Studi Akuntansi \& Keuangan Indonesia

Keterangan:

$\begin{array}{ll}\text { DPR } & \text { :Dividend Payout Ratio } \\ \text { INS } & : \text { Kepemilikan institusional } \\ \text { PCC } & : \text { Politically Connected Firms (1 apabila memiliki hubungan; } 0 \text { apabila } \\ & \text { tidak memiliki hubungan politik) } \\ \text { ROE } & : \text { Return on Equity } \\ \text { SIZE } & : \text { Pertumbuhan perusahaan } \\ \text { GROWTH } & : \text { Debt-to-Asset Ratio } \\ \text { DEBT } & : \text { Free Cash Flow Ratio } \\ \text { FCF } & \end{array}$

Metode Analisis Data

Penelitian merupakan penelitian kuantitatif yang menggunakan regresi Tobit dalam mengolah dan menganalisis hasil data. Regresi Tobit digunakan sebagai regresi tersensor yang dapat mengukur data tersensor seperti Dividend Payout Ratio (DPR), yang menjadi variabel dependen dalam penelitian. Variabel DPR hanya memiliki dua macam output. Apabila perusahaan tidak membayar dividen kepada pemegang saham maka akan memiliki nilai 0 dan nilai positif yang menunjukkan perusahaan membagikan dividen kepada pemegang saham.

\section{Hasil dan Diskusi}

\section{Statistik Deskriptif}

Dalam tabel berikut menunjukkan hasil uji statistik deskriptif dari seluruh variabel penelitian yang telah dilakukan dalam perusahaan non-keuangan yang terdaftar di BEI dalam 6 tahun, periode tahun 2012 hingga tahun 2017. Data diolah dengan menggunakan aplikasi STATA dan menghasilkan angka jumlah observasi, nilai rata-rata (mean), standar 
deviasi, nilai minimum, dan nilai maksimum untuk masing-masing variabel. Dapat dilihat dalam tabel, total observasi untuk seluruh variabel dalam penelitian ini yaitu berjumlah 1.554 observasi.

Tabel 3 Statistik Deskriptif

\begin{tabular}{|l|l|r|r|r|r|}
\hline Variable & \multicolumn{1}{l|}{ Obs. } & \multicolumn{1}{l|}{ Mean } & \multicolumn{1}{l|}{ Std. Dev. } & Minimum & Maksimum \\
\hline DPR & \multicolumn{1}{|l}{1554} & 0.2860 & 1.8246 & 0 & 58.4795 \\
\hline INS & \multicolumn{1}{|c|}{1554} & 0.1091 & 0.1376 & 0.00001 & 0.9835 \\
\hline PCC & \multicolumn{1}{|c|}{1554} & 0.5219 & 0.4997 & 0 & 1 \\
\hline ROE & 1554 & 0.0523 & 0.5517 & -14.8022 & 3.0663 \\
\hline SIZE & 1554 & $178,466,878$ & $63,462,126$ & 26,779 & $956,312,869$ \\
\hline GROWTH & 1554 & 0.2046 & 2.6622 & -0.9822 & 103.004 \\
\hline DEBT & 1554 & 0.3174 & 0.5120 & 0 & 7.8926 \\
\hline FCF & 1554 & 0.04507 & 0.4224 & -3.0328 & 1.6671 \\
\hline
\end{tabular}

\section{Hasil Uji Statistik Deskriptif - Variabel Dependen}

Variabel dependen penelitian ini adalah kebijakan dividen yang diukur menggunakan dividend payout ratio (DPR). Hasil menunjukkan bahwa variabel dividend payout ratio memiliki nilai rata-rata sebesar 0,286 dengan nilai standar deviasi sebesar 1,824. Statistik deskriptif DPR menunjukkan nilai minimum sebesar 0 dan nilai maksimum sebesar 58,479. Dari total 1.554 observasi, terdapat 812 observasi atau $52.25 \%$ dari total observasi memiliki nilai DPR 0.

Selain itu, perusahaan dengan nilai maksimum DPR terbesar adalah PT Media Nusantara Citra Tbk (MNCN) pada tahun 2014 dengan nilai DPR sebesar 58,48\%. MNC adalah sebuah perusahaan induk yang memiliki beberapa entitas anak dan menerima keuntungan dan/atau dividen dari entitas anak tersebut. Dengan mempertimbangkan 


\section{saki}

Studi Akuntansi \& Keuangan Indonesia

kondisi keuangan perseroan dan entitas anak, perusahaan membagikan dividen tunai minimum sebesar $45 \%$ dari laba bersih tahun sebelumnya. Pada tahun 2014, perusahaan meningkatkan jumlah dividen yang dibagikan menjadi 887.88 miliar rupiah dari laba per tahun buku 2014.

\section{Hasil Uji Statistik Deskriptif - Variabel Independen}

Terdapat dua variabel independen dalam penelitian ini, yaitu kepemilikan institusional (INS) dan koneksi politik dalam perusahaan (PCC). Berdasarkan hasil uji statistik deskriptif untuk INS, nilai rata-rata yang didapatkan yaitu 0,1091 dengan nilai standar deviasi 0,1376. Sedangkan untuk nilai minimum dan maksimum dari variabel INS masing-masing sebesar $0.001 \%$ dan $98.35 \%$. Terdapat 24 observasi atau sebesar $1.54 \%$ dari total observasi yang menunjukkan nilai INS sebesar $0,001 \%$. nilai maksimum untuk variabel INS sebesar 98,35\% yang berasal dari PT PP (Persero) Tbk (ULTJ) pada tahun 2016. PTPP merupakan perusahaan yang bergerak di bidang jasa konstruksi, pracetak, peralatan, properti dan realti, EPC, dan investasi. Nilai maksimum kepemilikan institusional ini dikarenakan berkurangnya jumlah saham yang dimiliki oleh kepemilikan perorangan domestik dan meningkatnya jumlah saham yang dimiliki institusi asing pada tahun 2016.

Untuk variabel koneksi politik (PCC), nilai rata-rata yang didapatkan adalah 0.5219 dengan nilai standar deviasi sebesar 0.4997. Variabel ini merupakan variabel dummy, makna angka 0 berarti perusahaan tidak memiliki koneksi politik dan angka 1 berarti perusahaan memiliki koneksi politik. Dari total 1.554 observasi yang menjadi sampel penelitian, $47.8 \%$ atau sebanyak 742 observasi menunjukkan angka 0 untuk variabel PCC dan sisanya sebanyak 52.2\% atau 811 observasi menunjukkan angka 1 .

Penelitian memiliki 5 variabel kontrol, yaitu Return on Equity (ROE), ukuran perusahaan (SIZE), pertumbuhan perusahaan (GROWTH), Debt-to-asset ratio (DEBT), dan Free Cash Flow (FCF) yang akan dibahas secara lebih detail pada paragraf selanjutnya. 


\section{saki}

Berdasarkan hasil uji statistik deskriptif untuk variabel kontrol yang pertama yaitu ROE, nilai rata-rata menunjukkan angka 0.0523 atau 5,23\% dengan nilai standar deviasi 0,5517 atau 55,17\%. Untuk nilai minimum ROE berada di angka -14.8022 yang didapatkan oleh PT Bumi Resources Tbk. (BUMI) di tahun 2013. Sedangkan untuk nilai maksimum didapatkan dari PT Sejahteraraya Anugrahjaya Tbk. (SRAJ) pada angka 3,0663 (306,63\%) di tahun 2012. Untuk variabel kontrol SIZE, nilai rata-rata dan standar deviasi berada pada angka 6,5446 dan 0,8412 secara berurutan. Nilai minimum SIZE yaitu 10,495 oleh PT Hanson International Tbk (MYRX) pada tahun 2014. Sedangkan untuk nilai maksimum SIZE didapatkan oleh sebuah perusahaan yang bergerak di bidang pertambangan dan perdagangan simpanan alam yaitu PT Aneka Tambang Tbk. (ANTM) pada tahun 2017.

Variabel GROWTH memiliki nilai rata-rata sebesar 0,2046 dan standar deviasi 2,6622 selama 6 tahun. Nilai minimum GROWTH berada di angka $-0,885$ atau $-88,5 \%$ oleh dari PT Bumi Resources Tbk (BUMI) di tahun 2014. Nilai maksimum GROWTH, didapatkan oleh PT J Resources Asia Pasifik Tbk (PSAB) pada tahun 2012 dengan angka 103\%. Variabel kontrol DEBT memiliki nilai rata-rata 0,3174 dengan standar deviasi 0,5120. Nilai terendah DEBT ada di angka 0 untuk 102 observasi atau sekitar 6,56\% dari total 1.554 observasi. Nilai tertinggi DEBT yaitu 1,0471 oleh PT Trikomsel Oke Tbk (TRIO) pada tahun 2015. Variabel kontrol FCF, nilai rata-rata dan standar deviasi yang dimiliki yaitu 0,0451 dan 0,4224 secara berurutan. Nilai minimum FCF berada di angka 3,0328 yang berada di tahun 2014 oleh PT Bumi Resources Tbk (BUMI), sedangkan untuk nilai maksimum FCF berada di angka 1,6671 di tahun 2012 yang didapatkan oleh PT Garda Tujuh Buana Tbk (GTBO). Pada tahun ini terjadi kenaikan yang signifikan pada angka arus kas dari aktivitas operasi perusahaan dari tahun 2011 ke tahun 2012.

\section{Pengujian Hipotesis}

\section{Tabel 4 Hasil Uji Hipotesis}




\begin{tabular}{|c|c|c|c|c|}
\hline Variabel & Deskripsi & Model 1 & Model 2 & Model 3 \\
\hline \multirow[t]{2}{*}{ INS } & Coefficient & -0.1012 & & -0.2016 \\
\hline & P-value & $(0.195)$ & & $(0.103)$ \\
\hline \multirow[t]{2}{*}{ PCC } & Coefficient & & $0.0456 * *$ & 0.0256 \\
\hline & P-value & & $(0.0725)$ & $(0.252)$ \\
\hline \multirow[t]{2}{*}{ INS*PCC } & Coefficient & & & 0.2107 \\
\hline & P-value & & & $(0.179)$ \\
\hline \multirow[t]{2}{*}{ ROE } & Coefficient & $0.1835 * * *$ & $0.1832 * * *$ & $0.1815 * * *$ \\
\hline & P-value & $(0.0025)$ & $(0.0025)$ & $(0.0025)$ \\
\hline \multirow[t]{2}{*}{ SIZE } & Coefficient & -0.0065 & -0.0168 & -0.0176 \\
\hline & P-value & $(0.378)$ & $(0.218)$ & $(0.209)$ \\
\hline \multirow[t]{2}{*}{ GROWTH } & Coefficient & 0.0097 & 0.0088 & 0.0094 \\
\hline & P-value & $(0.371)$ & $(0.382)$ & $(0.375)$ \\
\hline \multirow[t]{2}{*}{ DEBT } & Coefficient & -0.0639 & -0.0599 & -0.0579 \\
\hline & P-value & $(0.175)$ & $(0.191)$ & (0.199) \\
\hline \multirow[t]{2}{*}{ FCF } & Coefficient & -0.0462 & $-0.0507 * *$ & -0.0510 \\
\hline & P-value & $(0.191)$ & $(0.0125)$ & $(0.167)$ \\
\hline $\begin{array}{l}* * * \text { Signifikan } \\
* * \text { Signifikan } \\
* \text { Signifikan pa }\end{array}$ & $\begin{array}{l}\text { pada level } \alpha=0,0 \\
\text { pada level } \alpha=0,05 \\
\text { da level } \alpha=0,10\end{array}$ & & & \\
\hline
\end{tabular}

\section{Temuan dan Interpretasi Hasil Penelitian}

Tabel 4 menggambarkan ringkasan dari hasil uji hipotesis pada ketiga model penelitian ini menggunakan regresi tobit. Pada hasil regresi tobit, terdapat nilai yang menunjukkan besar varian data yang dapat dijelaskan oleh model. Pseudo- $\mathrm{R}^{2}$ merupakan bentuk pengukuran goodness of fit pada regresi tobit (Bierens, 2004). Umumnya, semakin tinggi nilai $\mathrm{R}^{2}$ pada suatu model, menunjukkan bahwa model yang digunakan sudah sesuai dengan data penelitian. Pseudo- $R^{2}$ untuk model 1 sebesar 17,82 persen, untuk model 2 sebesar 18,49 persen dan model 3 sebesar 18,83 persen. Hal ini menjelaskan bahwa model 


\section{saki}

penelitian cenderung memiliki respons yang lebih baik dengan menggunakan variabelvariabel yang digunakan pada model tiga.

Pada model 1 dan 3 dapat terlihat bahwa kepemilikan institusiona (INS) tidak berpengaruh signifikan terhadap kebijakan dividen ( $p$-value 0.195 pada model 1 dan $p$-value 0.103 pada model 3). Sedangkan variable koneksi politik (PCC) menunjukkan hubungan positif signifikan pada model 2 (koefisien 0.0456 dan $p$-value 0.0725 ). Hasil ini berbeda dengan model 3 dimana PCC tidak berpengaruh signifikan terhadap kebijakan dividen ( $p$-value 0.252). Begitu pula dengan variable interaksi antara INS dan PCC tidak menunjukkan hubungan signikan terhadap kebijakan dividen ( $p$-value 0.179).

Selanjutnya, berdasarkan hasil regresi tobit dapat dilihat pada tabel bahwa variabel return on equity (ROE) menunjukkan $\mathrm{P}$ value yang signifikan pada level $1 \%$ dengan variabel DPR pada ketiga model. Ketiga model penelitian menunjukkan pengaruh variabel ROE terhadap kebijakan dividen bersifat positif, yang dapat dilihat berdasarkan koefisien dan nilai t yang bernilai positif. Sesuai dengan hasil penelitian Benjamin et al. (2016), hubungan positif antara variabel ROE dengan DPR menunjukkan bahwa kedua variabel memiliki hubungan yang berbanding lurus. Hal ini menunjukkan bahwa semakin tinggi penghasilan sebuah perusahaan, akan semakin banyak jumlah dividen yang dibagikan oleh perusahaan. Variabel GROWTH menunjukkan adanya pengaruh tidak signifikan terhadap kebijakan dividen. Kemudian untuk variabel kontrol, terdapat variabel ukuran perusahaan (SIZE), DEBT juga tidak berpengaruh signifikan terhadap variabel DPR. Sedangkan variable FCF hanya berpengaruh signifikan pada model 2.

\section{Diskusi}

\section{Kepemilikan Institusional dan Pembagian Dividen}

Hasil dari uji regresi tobit yang dilakukan dalam menguji pengaruh dari dua variabel independen penelitian, yaitu kepemilikan institusional (INS) dan koneksi politik (PCC) terhadap variabel dependen kebijakan dividen yang diukur dari Dividend Payout Ratio (DPR) di perusahaan non-keuangan BEI 2012 hingga 2017 menunjukkan hasil yang 
Studi Akuntansi \& Keuangan Indonesia

berbeda-beda. Hasil dari uji model regresi dari hipotesis pertama menunjukkan bahwa terdapat pengaruh tidak signifikan antara kepemilikan institusional dengan kebijakan dividen perusahaan. Ini berarti kepemilikan institusional bukan merupakan faktor yang mempengaruhi kebijakan dividen perusahaan.

Jika menggali lebih dalam pada statistik deskriptif pada penelitian ini, kepemilikan institusional rata-rata hanya 10,91 persen, bahkan dari 1.554 observasi, sebanyak 24 observasi memiliki kepemilikan institusional di bawah 0,001 persen. Hal tersebut menunjukkan bahwa tingkat kepemilikan institusional rata-rata perusahaan-perusahaan yang terdaftar di BEI pada periode 2012 - 2017 tergolong rendah dan tidak dominan. Ini berarti tidak dominannya tingkat kepemilikan institusional tidak dapat mempengaruhi kebijakan dividen perusahaan. Hasil penelitian ini mendukung penelitian Nguyen dan Li (2020) yang menemukan bahwa variabel kepemilikan institusional tidak berpengaruh terhadap kebijakan dividen perusahaan.

\section{Political Connection dan Pembagian Dividen}

Variabel PCC, hasil menunjukkan adanya hubungan positif signifikan terhadap DPR (Model 2). Hasil ini sejalan dengan penelitian terdahulu oleh Fung et al. (2014) yang melakukan penelitiannya di China. Dalam penelitiannya di China, dikatakan bahwa perusahaan dengan koneksi politik mendapatkan keuntungan dimana mereka memiliki akses yang lebih banyak ke kepada sumber-sumber dalam pemerintahan. Apabila dihubungkan dengan signalling theory dari dividen, perusahaan dengan koneksi politik ini membagikan lebih banyak dividen dengan tujuan menunjukkan bahwa perusahaan memiliki prospek masa depan yang bagus dan kelebihan mereka dibandingkan perusahaan tanpa koneksi politik. Graham et al. (2006) menyatakan bahwa sejumlah perusahaan mempertahankan sebuah pola yang reguler dalam membagikan dividen dikarenakan investor cenderung lebih menyukai adanya pola tertentu dengan alasan tertentu. Dengan 
Studi Akuntansi \& Keuangan Indonesia

pernyataan ini, maka pembagian dividen secara rutin dan teratur dapat menarik anggota pemerintah sebagai salah satu pemegang saham.

Politically Connected Firms yang memiliki kepemilikan institusional dan Kebijakan Dividen

Ketika variabel INS dan PCC berinteraksi, hasil uji menunjukkan hasil yang positif tidak signifikan terhadap DPR. Artinya interaksi antara koneksi politik dan kepemilikan institusional tidak mempengaruhi kebijakan dividen perusahaan. Hasil penelitian kami menunjukkan rata-rata investor institusional hanya 10,91 persen sehingga merupakan pihak minoritas. Berdasarkan hasil temuan kami pihak institusional yang semestinya memegang peranan krusial ternyata menjadi pihak minoritas sehingga sulit untuk mempengaruhi keputusan pembagian dividen. Meskipun kepemilikan institusional diinteraksikan dengan koneksi politik, nyatanya bukan menjadi factor yang memengaruhi kebijakan dividen. Hasil penelitian ini berlawanan dengan penelitian Benjamin et al. (2016) yang menunjukkan interaksi INS dan PCC signifikan positif terhadap DPR karena penelitian tersebut mempertimbangkan juga faktor ekspropriation concern, tipe perusahaan PCC, apakah tergolong perusahaan yang sedang bertumbuh (growth) atau perusahaan dengan pertumbuhan yang rendah, sedangkan pada penelitian kami tidak memasukkan variabelvariabel tersebut.

\section{Kesimpulan, Implikasi, dan Keterbatasan}

Penelitian menemukan kepemilikan institusional tidak berpengaruh terhadap kebijakan dividen. Penelitian juga menemukan bahwa koneksi politik memiliki pengaruh positif signifikan terhadap kebijakan dividen (Model 2). Hasil uji hipotesis 3 menunjukkan interaksi antara kepemilikan institusional dan koneksi politik tidak berpengaruh terhadap kebijakan dividen. 


\section{saki}

Studi Akuntansi \& Keuangan Indonesia

Berdasarkan hasil penelitian, terdapat sejumlah implikasi yang telah ditemukan yang dibagi menjadi tiga bagian yaitu implikasi yang dapat bermanfaat bagi akademisi, perusahaan, dan investor. Bagi akademisi, penelitian ini diharapkan dapat menambah literatur penelitian mengenai kepemilikan institusional dan koneksi politik pada perusahaan terhadap kebijakan dividen di Indonesia dengan menggunakan model regresi tobit. Selanjutnya bagi investor, penelitian ini diharapkan membuat investor menyadari pentingnya koneksi politik sehingga lebih selektif dalam menanamkan modalnya dalam suatu perusahaan guna mendapat return dalam bentuk dividen yang lebih tinggi karena koneksi politik berhubungan positif dengan kebijakan dividen.

Keterbatasan utama yang teridentifikasi dalam penelitian ini adalah kriteria koneksi politik yang digunakan berdasarkan penelitian terdahulu oleh Habib dan Muhammadi (2018), yaitu kurangnya keakuratan untuk definisi koneksi politik itu sendiri. Penjabaran definisi koneksi politik pun masih belum terlalu jelas mengenai badan-badan, organisasi atau lembaga negara apa saja yang menjadi bagian dari anggota politik. Selain itu, penelitian juga mengalami kesulitan dalam mendefinisikan bahwa seorang anggota dalam perusahaan memiliki hubungan keluarga (ayah, ibu, atau anak) dengan seorang politisi, sehingga memungkinkan bahwa masih ada anggota yang ternyata merupakan anggota keluarga politisi tapi tidak masuk ke dalam sampel penelitian. Penelitian selanjutnya dapat menggunakan klasifikasi koneksi politik dengan kriteria yang lebih rinci dan akurat seperti yang ditetapkan Faccio (2006) misalkan besarnya saham pengendali atau jumlah direksi yang terkait atau dimiliki anggota parlemen, menteri, kepala pemerintahan baik ditingkat nasional maupun daerah, partai politik maupun kedekatan dengan politisi.

\section{Daftar Pustaka}




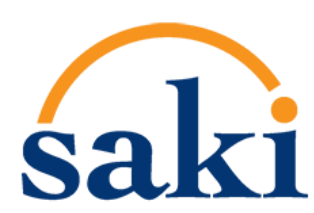

Studi Akuntansi \& Keuangan Indonesia

Al-Malkawi, H. N., Pillai, R., \& Rafferty, M. (2010). Dividend Policy: A Review of Theories and Empirical Evidence. International Bulletin of Business Administration IssuE, 9 (1), 171200.

Ayers, B.C., Ramalingegowda, S. and Yeung, P.E. (2011). Hometown advantage: the effects of monitoring institution location on financial reporting discretion. Journal of Accounting and Economics, 52 (1), 41-61.

Balagobei, S. \& Thiruchchenthurnathan, T. (2016). Impact of Ownership Structure on Dividend Payout Policy: An Empirical Study on Listed Plantation Companies in Sri Lanka. Research Journal of Finance and Accounting, 7 (14), 93-98.

Bandi, B., Phua, L. K., Setiawan, D., \& Trinugroho, I. (2015). Ownership Structure and Dividend Policy in Indonesia. Journal of Asia Business Studies, 10 (3), 230-252.

Benjamin, S. B., Wahab, E. A., \& Zain, M. M. (2016). Political connections, institutional investors, and dividend payouts in Malaysia. Pacific Accounting Review, 28 (2), 153-179.

Bierens, Herman J. (2004). Introduction to the Mathematical and Statistical Foundations of Econometrics. Cambridge University Press.

Bliss, M. A. \& Gul, F. A. (2012). Political connection and cost of debt: some Malaysian evidence. Journal of Banking and Finance. 36 (8), 2344-2350.

Cao, L., Du, Y. and Hansen, J.O. (2017). Foreign institutional investors and dividend policy: Evidence from China. International Business Review, 26 (5) 816-827.

Chung, K. H. dan Zhang, H. (2011). Corporate Governance and Institutional Ownership. Journal of Finance and Quantitative Analysis, 46 (1), 247-273.

Easterbrook, F.H. (1984). Two agency-cost explanations of dividends. American Economic Review, $74(4), 650-659$.

Edison, A. (2017). Struktur Kepemilikan Asing, Kepemilikan Institusional dan Kepemilikan Manajerial Pengaruhnya Terhadap Luas Pengungkapan Corporate Social Responsibility (CSR) (Studi Empiris Pada Perusahaan Sektor Utama Yang Terdaftar Di Bursa Efek Indonesia Tahun 2013-2014). Jurnal Bisnis Dan Manajemen Fakultas Ekonomi Universitas Widyatama, 11(2), 164-175.

Faccio, M., Lang, L.H.P. \& Young, L. (2001). Dividends and expropriation. American Economic Review, 91 (1), 54-78.

Faccio, M. (2006). Politically connected firms. The American Economic Review, 96 (1), 369-386.

Ferilianto, A., Mardani, R.M., \& Wahono B. (2018). Pengaruh Kepemilikan Manajerial, Institusional, Leverage Terhadap Kebijakan Dividen (Studi Kasus pada Perusahaan Perbankan yang Terdaftar di BEI Periode 2015-2017). Jurnal Ilmiah Riset Manajemen, 7(13), 57-68.

Fung, H. G., Huang, D., Shen, C. H., \& Su, Z. (2014). Cash dividends, expropriation, and political connections: Evidence from China. International Review of Economics and Finance, 29, 260-270.

Gitman, L. J., Megginson, W. L. \& Smart, S. B. (2007). Corporate Finance (Second Edition). Thomson, South-Western.

Glen, J.D., Karmokolias, Y., Miller, R.R. \& Shah, S. (1995, July 31). Dividend policy and behaviour in emerging markets: to pay or not to pay. Retrieved July 29, 2020, from https://documents.worldbank.org/en/publication/documentsreports/documentdetail/325441468741588836/dividend-policy-and-behavior-inemerging-markets-to-pay-or-not-to-pay

Goldman, E., Rocholl, J. \& So, J. (2009). Do Politically Connected Boards Affect Firm Value?. Review of Financial Studies, 22 (6), 2331-2360.

Graham, J. \& Kumar, A. (2006). Dividend Preference of retail investors: Do Dividend clienteles exist?. Journal of Finance. 6(3), 1305-1336.

Grinblatt, M. \& Keloharju, M. (2000). The Investment Behavior and Performance of Various Investor Types: a study of Finland's unique data set. Journal of Financial Economics, 55, 43-67.

Grinsten, Y. \& Michaely, R. (2005). Institutional Holdings and Payout Policy. Journal of Finance, 60 (3), 1389-1426. 


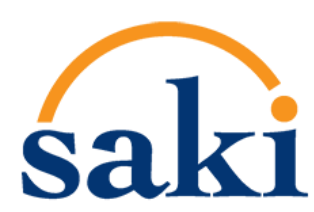

Studi Akuntansi \& Keuangan Indonesia

Habib, A., \& Muhammadi, A. H., (2018). Political connections and audit report lag: Indonesian evidence. International Journal of Accounting \& Information Management, 26 (1), 5980.

Haron, H., James, K., Wahab, E. A. A. \& Zain, M. M., (2009). Institutional investors, political connection and audit quality in Malaysia. Accounting Research Journal, 22 (2), 167195.

Jensen, M. C. (1986). Agency Costs of Free Cash Flow, Corporate Finance, and Takeovers. The American Economic Review, 76 (2), 323-329.

Jensen, M.C., \& Meckling, W., (1976). Theory of the firm: managerial behavior, agency costs and ownership structure. Journal of Financial Economic, 3, 305-360.

Kurniawati, L., Manalu, S., \& Octavianus, R. J. N. (2015). Pengaruh Kepemilikan Institusional Terhadap Kebijakan Dividen, Dan Harga Saham. Jurnal Manajemen, 15(1), 59-74.

La Porta, R., Lopez-de-Silanes, F., Shleifer, A. \& Vishny, R.W. (2000). Agency problems and dividend policies around the world. Journal of Finance, 55 (1), 1-33.

Larkin, Y., Leary, M. T., \& Michaely, R. (2016). Do Investors Value Dividend-Smoothing Stocks Differently?. Management Science, 63(12), 4114-4136.

Leuz, C. \& Oberholzer-Gee, F. (2006). Political relationships, global financing, and corporate transparency: evidence from Indonesia. Journal of Financial Economics, 81 (2), 411-439.

Miller, M. \& Modigliani, F. (1961). Dividend Policy, Growth, and the Valuation of Shares. The Journal of Business, 34(4), 411-433.

Megginson, W. L., \& Smart, S.B. (2008). Introduction to Financial Management (Second edition). Ohio: South-Western Cengage Learning.

Nguyen, T. \& Li, H. (2020). Dividend Policy and Institutional Holdings: Evidence from Australia. International Journal of Financial Studies, 8(1), 1-14.

Nugraheni, N. P. \& Mertha, M. (2019). Pengaruh Likuiditas Dan Kepemilikan Institusional Terhadap Kebijakan Dividen Perusahaan Manufaktur. E-Jurnal Akuntansi, 26, 736- 762.

Nys, E., Tarazi, A. \& Trinugroho, I. (2015). Political connections, bank deposits and formal deposit insurance. Journal of Financial Stability. 19 (1), 83-104.

Purbasari, D. P. (2006). Political Connection, Trade Protection, and Multinational Corporation: Firm-level Evidence of Patronage in Indonesia (Doctoral dissertation). Retrieved from Dissertations and Theses database. (UMI No. 3212109)

Rais, B. N. \& Santoso, H. F. (2017). Pengaruh Kepemilikan Manajerial, Kepemilikan Institusional, Profitabilitas dan Ukuran Perusahaan Terhadap Kebijakan Dividen. Jurnal Ilmiah Manajemen Bisnis, 17(2), 111-124.

Roy, A. (2015). Dividend Policy, Ownership Structure and Corporate Governance: An Empirical Analysis of Indian Firms. Indian Journal of Corporate Governance, 8 (1), 1-33.

Shim, J. K., \& Siegel, J. G. (2007). Schaum's Outline of Financial Management (3rd ed.). The McGraw-Hill Companies.

Shin, J. Y \& Seo, J. (2011). Less Pay and More Sensitivity? Institutional Investor Heterogeneity and CEO Pay. Journal of Management, 37 (6), 1719-1746.

Shleifer, A. \& Vishny, R.W. (1986). Large shareholders and corporate control. Journal of Political Economy, 94 (3), 461-488.

Shleifer, A. \& Vishny, R.W. (1997). A Survey of Corporate Governance. Journal of Finance, 52 (2), 737-783.

Sumartha, E. (2016). Pengaruh Struktur Kepemilikan Terhadap Kebijakan Dividen Pada Perusahaan Manufaktur. Jurnal Economia, 12 (2), 167-182.

Thanatawee, Y. (2013). Ownership Structure and Dividend Policy: Evidence from Thailand. International Journal of Economics and Finance, 5 (1), 121-132.

Zygula, A. (2017). Impact of Foreign Ownership on Dividend Policy in Poland. Financial Internet Quarterly, 13 (4), 76-88 